\title{
La Restauración en Inglaterra y la poesía satírica: The Medal de John Dryden
}

\author{
Mercedes Vella Ramírez \\ Universidad de Córdoba
}

\begin{abstract}
Resumen: Trabajo que lleva a cabo una breve revisión histórica del periodo de la Restauración, tratando de analizar la causa de la proliferación de poemas satíricos en Inglaterra. El ejemplo ofrecido es The Medal, de John Dryden, uno de los poemas más representativos de la época, dedicado a desprestigiar la figura del Conde de Shaftesbury, antiguo aliado de Carlos II, que decidió apoyar al Duque de Monmouth como sucesor al trono.
\end{abstract}

Abstract: In this work I am concerned with a brief historical revision of the Restauration period, where I discuss the causes of proliferation of satiric poems in England. The example chosen is The Medal by John Dryden, one of the most representative poems of the period. It is devoted to criticize the figure of the Count of Shaftesbury, an old ally of Charles II who decided to support the Duke of Monmouth as the successor to the throne.

Palabras clave: Traducción poética. Sátira.

Key Words: Poetic Translation. Satire

\section{BREVE RESEÑA HISTÓRICA}

En el último tercio del siglo XVII se produce en Inglaterra uno de los cambios más abruptos en cuanto a estilo literario se refiere. Las diferencias que existen entre los poetas metafísicos y las posteriores obras de Butler, Dryden o Swift marcan una clara línea divisoria entre una y otra tendencia. El papel de la literatura va a ser redefinido en función de un cambio de enfoque cultural, que a su vez viene provocado por los acontecimientos socio-políticos del momento. Las consecuencias sobre la poesía y la prosa del momento no se van a hacer esperar. Para comprender mejor por qué la época de la restauración se identifica con frecuencia con la edad de oro de la sátira, es imprescindible realizar una pequeña reflexión histórica, que nos ubique en el contexto político-social del momento.

En 1660, tras el fallido intento republicano de Cromwell, vuelve a instaurarse en Inglaterra la monarquía. Carlos II, legítimo heredero del trono de Inglaterra y exilado en Francia durante los últimos veinte años, es invitado a volver al país y ocupar el trono. Durante los primeros dieciocho años del reinado de Carlos II, de gustos, costumbres y tendencias francesas, se fue fraguando un incremento gradual del descontento de los 
ciudadanos, de manera que a finales del XVII el número de quejas sobre su gestión al frente de país era desorbitado. A finales de 1670 era ya evidente que el rey no iba a tener un heredero legítimo, pues se sabía que la reina no era una mujer fértil. Su sucesor normal en este caso, hubiera sido su hermano Jacobo, Duque de York, hombre de fe católica, respaldado por los conservadores y por el propio Carlos II. Los liberales, sin embargo, apadrinaron un manifiesto para excluir a los católicos del trono ('The Exclusion Bill') y permitir que el mayor de los hijos ilegítimos de Carlos, el Duque de Monmouth, le sucediera en el trono. El principal líder liberal, que apoyaba la sucesión de Monmouth, oponiéndose así al rey, era Anthony Ashley Cooper, Conde de Shaftesbury, quién habia comenzado su carrera política tras la Restauración como un cercano y potente aliado del rey Carlos, que en recompensa a su ayuda le otorgó el título de Conde. Las actividades de Shaftesbury en contra de la monarquía alcanzaron tal magnitud que finalmente fue ordenado encarcelar en la Torre de Londres y juzgado por alta traición. No obstante, fue redimido de sus cargos y sus seguidores mandaron acuñar una medalla en su honor (la obra de Dryden The Medal que analizamos y traducimos en este artículo hace referencia a esta cuestión). La situación política era, como hemos visto, bastante compleja y el descontento de la población considerable.

En relación con las costumbres sociales y religiosas, los puritanos de la etapa anterior habian impuesto un excesivo rigor en el comportamiento, que como contrapartida dio rienda suelta a un mal entendido liberalismo y a una relajación de costumbres surgidas en la corte y encabezadas por el propio rey, quién reconoció al menos a catorce de entre sus numerosos hijos ilegítimos. El momento, en general, no podia ser más propicio para el desarrollo de la sátira, cuya máxima expansión como género suele darse en épocas y situaciones en las que las sociedades se rigen por estándares hipócritas y transigentes, que consideran virtud lo que objetivamente es vicio, y en las que una simple reprimenda moral no tendría ningún efecto. En estos momentos, en los que la sociedad realmente ha sufrido una pérdida de valores, la falta de referencias hace que el autor se vea obligado a recurrir a la ironía para poder transmitir una visión crítica de la situación, al tiempo que intenta ofrecer con su obra una moralidad implícita, y es así como surge el autor satírico.

Pero en este momento se dan además otros factores en Inglaterra, que contribuyen notablemente a que la poesía satírica tenga en el periodo inmediatamente posterior a la Restauración un uso sin precedentes. En primer lugar, desde un punto de vista político-social en la Inglaterra del momento se pueden observar dos grupos claramente diferenciados: por una parte encontramos a aquellos individuos partidarios del cristianismo tradicional, que mantienen la fe en las escrituras, que apenas toleran a 
aquellos que no comparten su creencia anglicana y que no están dispuestos a sacrificar ni sus creencias ni sus tradiciones sociales y políticas; por otro lado, encontramos a un grupo de individuos que ve en el poder creciente de la ciencia el camino para reformar la sociedad, que no mantienen una relación estrecha con la religión y que están deseosos de que se produzcan cambios sociales y políticos. De estas dos tendencias surgirán los dos partidos políticos que dominarán el panorama en la Inglaterra del siglo XVIII: los conservadores, tradicionalistas anglicanos que defienden la religión del estado y las instituciones existentes y los liberales, tendentes a una reforma más racional, que opinan que la religión debe estar al servicio de la razón en aras del desarrollo del comercio y el bienestar político y social. La existencia de estos dos partidos claramente diferenciados apoya la explosión de la sátira política como un instrumento de desacreditación de la parte contraria; la manera más eficaz de alejar del poder a los rivales políticos consistía en desprestigiarlos ante la opinión pública, haciendo escarnio y mofa de ellos y de sus acciones, en composiciones satíricas. Este es el caso concreto de The medal.

Otra cuestión a destacar es el hecho de que las nuevas condiciones sociales que se estaban desarrollando implicarán un crecimiento de las ciudades, y en especial de Londres, en detrimento de los asentamientos rurales; muchos miembros de la aristocracia, que antes vivían en el campo, pasarán cada vez más tiempo en Londres, y la sociedad londinense, cada vez más moderna y formada, constituirá una audiencia perfecta para la sátira. No debemos olvidar que este género requiere tener una audiencia con cierta sofisticación, la sátira precisa un lector inteligente que sea consciente de los acontecimientos, los personajes o las conductas que se pretenden satirizar y que sea capaz de compartir la ironía del lenguaje. De manera que nos encontramos con una sociedad ilustrada, de costumbres morales relajadas, que vive un clima de alta crispación política y que siente la necesidad de racionalizar la conducta pública. Es el caldo de cultivo ideal para que la sátira se convierta en el género literario por excelencia, que permite, a través de la ironia, moralizar sobre temas públicos concretos con una clara intención didáctica.

\section{LA SÁTIRA EN LA INGLATERRA DEL SIGLO XVII}

Parece lógico llevar a cabo en este apartado una definición, por somera que sea, de lo que entendemos por sátira, o para ser más precisos de cual es la esencia de la sátira del siglo XVII en Inglaterra ${ }^{1}$.

\footnotetext{
1 Me limito en este punto a citar algunas definiciones del diccionario y no a una revisión histórica de la sátira en Grecia y Roma, que ya ha sido llevada a cabo en algún trabajo de este mismo número.
} 
El término 'sátira' aparece definido en el Merrian Webster Dictionary como 'a literary work holding up human vices and follies to ridicule or scorn' y en el Wordsmyth Thesaurus Dictionary como 'a literary or dramatic work that ridicules or derides human vice or foolishness, usually through the use of parody and irony'. En ambas definiciones, así como en todas las consultadas, se echa de menos una alusión al carácter didáctico de la sátira, porque la esencia de la sátira es, sin duda, la agresión y la crítica; pero la crítica lleva implícita una toma de posición respecto a lo que está bien y lo que está mal, una toma de posición cuyo fin último es fundamentalmente didáctico.

La sátira de mejor calidad no persigue dañar o herir con su visión ridícula de una situación o comportamiento, sino que más bien pretende que el lector sienta repulsión frente a ese comportamiento 'viciado' y se aleje de él. Desde esta perspectiva, podriamos decir que la sátira tiene mucho más de constructiva que de destructiva, y así es como la ven la inmensa mayoría de los autores satíricos, tal y como estas líneas de Swift, extraídas de sus Verses on the Death of Dr. Swift nos revelan:

As with a moral View design'd

To cure the Vices of Mankind:

His vein, ironically grave,

Expos'd the Fool, and lash'd the Knave.

Yet, Malice never was his Aim;

He lash'd the Vice but spar'd the Name.

No Individual could resent,

Where Thousands equally were meant.

His Satyr points at no Defect,

But what all Mortals may correct. ...

(vv. 329-32, 475-80) $)^{2}$

De hecho, la diferencia fundamental entre la sátira y la comedia, genero con el que comparte muchas de sus características, es que la sátira tiene, por regla general, una clara y abierta intención didáctica, una clara lección moral, que persigue, utilizando la mofa y el ridículo como herramientas, apartarnos de conductas consideradas ilícitas o poco éticas y guiarnos a comportamientos más acordes con la opinión que el autor tiene de lo correcto.

Partiendo de esta idea de la sátira como una composición de propósito correctivo, dañar, herir o ridiculizar no constituyen el fin último de la sátira, sino que más bien es el vehículo que ésta utiliza para conseguir su

\footnotetext{
${ }^{2}$ Verses on the Death of Doctor Swift. Written by Himself: Nov. 1731. London: Printed for C. Bathurst, at The Middle Temple-Gate in Fleetstreet. MDCCXXXIX. Fo.
} 
verdadero fin, más relacionado con la preservación de costumbres o tradiciones, la reafirmación de valores y/o la necesidad de reforma.

\section{JOHN DRYDEN: THE MEDAL}

La primera obra de John Dryden (1631-1700) en conseguir notoriedad pública son sus Heroic Stanzas (1659), escritas para conmemorar la muerte de Cromwell; al año siguiente y para conmemorar la restauración en el trono de Carlos II escribió Astraea Redux y Panegyric on the coronation (1661); en su extenso poema Annus Mirabilis (1677) aparece recogida su visión de la victoria naval inglesa sobre los holandeses. Considerado uno de los más prominentes dramaturgos ingleses, Dryden comenzó escribiendo comedias para ganarse la vida, entre éstas podríamos destacar The Rival Ladies (1664), Ladies à la Mode (1668) y Marriage à la Mode (1672); entre sus dramas heroicos son destacables The Indian Queen (1664), una especie de ópera con música de Purcell, The Conquest of Granada (dos partes, 167071) y Aurenz- Zebe (1675); su versión de la historia de Marco Antonio y Cleopatra, All for Love (1678), es considerada por muchos críticos como su mejor obra y la mejor tragedia de la época de la Restauración.

Parece ser que Dryden comenzó a escribir sátiras más por sugerencia que por propia convicción política; no olvidemos que entre sus obligaciones como poeta laureado ${ }^{3}$ estaba la de escribir algunas obras al servicio de la corona. Cuando Dryden se acerca a la sátira tiene tras de sí una larga carrera literaria, de tal modo que su dominio de la lengua poética, unido a su gran talla intelectual hicieron que la sátira política alcanzara en sus manos su punto de clímax y máxima calidad.

Entre sus sátiras politicas, centradas casi en exclusiva en las figuras de Monmouth y Shaftesury son especialmente destacables Absalon y Achitophel (1681), The Second Part of Absalon y Achitophel (1682) y The Medal, A Satyre against Sedition (1682), que me ha parecido la más apropiada como representativa de la agudeza de Dryden y de la cual he llevado a cabo su versión al castellano en alejandrinos.

\footnotetext{
${ }^{3} \mathrm{El}$ nombramiento de poeta laureado es otorgado por el rey, que realiza su elección sobre un grupo de poetas propuestos por el Primer Ministro. Es un cargo vitaliceo y entre sus obligaciones está el componer poemas para la corte y para ocasiones especiales de carácter nacional. El primer poeta laureado fue Ben Jonson, en 1616, y el último y actual Andrew Motion, nombrado en 1999. También fueron poetas laureados John Dryden (1668), William Wordsworth (1843), John Mansfield (1930) o Ted Hughes (1984), por nombrar algunos de ellos.
} 
1 Of all our antic sights and pageantry,

2 Which English idiots run in crowds to see,

3 The Polish Medal bears the prize alone;

4 A monster, more the favourite of the town

5 Than either fairs or theatres have shown.

6. Never did art so well with nature strive,

7 Nor ever idol seemed so much alive;

8 So like the man, so golden to the sight,

9 So base within, so counterfeit and light.

10 One side is filled with title and with face;

11 And, lest the king should want a regal place,

12 On the reverse a Tower the town surveys,

13 O'er which our mounting sun his beams displays.

14 The word, pronounced aloud by shrieval voice,

15 Lætamur, which, in Polish, is Rejoice;

16 The day, month, year, to the great act are joined,

17 And a new canting holiday designed;

18 Five days he sat for every cast and look,

19 Four more than God to finish Adam took.

20 But who can tell what essence angels are?

21 Or how long heaven was making Lucifer?

22 Oh, could the style that copied every grace,

23. And ploughed such furrows for an eunuch face,

24 Could it have formed his ever-changing will,

25 The various piece had tired the graver's skill!

26 A martial hero first, with early care,

27 Blown, like a pigmy by the winds, to war;

28 A beardless chief, a rebel ere a man;

29 So young his hatred to his prince began.

30 Next this, how wildly will ambition steer!

31 A vermin wriggling in the usurper's ear;

32 Bartering his venal wit for sums of gold,

33 He cast himself into the saint-like mould;

34 Groaned, sighed, and prayed, while godliness was gain,

35 The loudest bagpipe of the squeaking train.

36 But, as 'tis hard to cheat a juggler's eyes,

37 His open lewdness he could ne'er disguise.

38 There split the saint; for hypocritic zeal

39 Allows no sins but those it can conceal: 
De estos nuestros vestigios ancestrales y boatos, que los tontos ingleses se agolpan para ver, la medalla polaca ${ }^{4}$ se lleva el primer premio; un monstruo, apreciado por toda la ciudad más que los que se exhiben en ferias o teatros. Nunca pelearon tanto arte y naturaleza, ni ídolo alguno pareció estar tan vivo. Tan semejante al hombre, tan dorada a la vista, tan compacta por dentro, tan falsa y tan ligera. La cara nos enseña el título y el rostro $y$, para que el rey en ella no cupiera, en la cruz una torre vigila la ciudad; sobre ella el sol irradia sus rayos desde el fondo. La palabra 'lætamur', que es 'júbilo' en polaco, pronunciada en voz alta por voz autoritaria. El día, el mes y el año se unen al gran acto y un nuevo día festivo quedó asi fijado, tardó unos cinco días para cada mirada, usando asi unos cuatro más que Dios para Adán. Mas ¿quién puede relatarnos la esencia de los ángeles? ¿O cuánto tardó el cielo en crear a Lucifer? ¿Podría el estilo que copió cada gracia y marcó tales surcos en un rostro de eunuco haberle dado forma a su deseo cambiante? ¡La pieza tan diversa, al grabador agota! Primero un marcial héroe, con prematuro cargo llevado, cual pigmeo por el viento, a la guerra; un jefe aún imberbe, rebelde antes que hombre, comenzó así de joven a odiar a su príncipe. Tras esto, jcuán salvaje la ambición lo gobierna! un canalla reptando, al usurpador próximo, trocando su ingenio infiel por sumas de oro, se coloca a sí mismo en el molde de un santo; suspiró y oró, su piedad fue aumentando, la gaita más sonora de la chirriante corte. Mas como es muy dificil timar al propio mago, su insolente lascivia no pudo disfrazar.

Ahí acabó el santo, pues el celo hipócrita solo acepta pecados si los puede esconder:

\footnotetext{
${ }^{4}$ La alusión a Polonia hace referencia a la costumbre de la época de acuñar medallas para conmemorar los diversos acontecimientos políticos, como cuando se acuñó una medalla para celebrar la elección de Sobieski como rey de Polonia. Sin embargo, Morris Freedman, en su artículo "John Milton and the King of Poland", alude a la posibilidad de que Dryden quisiera poner de manifiesto la ambición del Conde de Shaftesbury en ser nombrado rey de Polonia; idea ésta, que será posteriormente descartada por Wasserman, en "The meaning of 'Poland' in The Medal".
} 
40 Whoring to scandal gives too large a scope;

41 Saints must not trade, but they may interlope:

42 The ungodly principle was all the same;

43 But a gross cheat betrays his partner's game.

44 Besides, their pace was formal, grave, and slack;

45 His nimble wit outran the heavy pack;

46 Yet still he found his fortune at a stay,

47 Whole droves of blockheads choking up his way;

48 They took, but not rewarded, his advice;

49 Villain and wit exact a double price.

50 Power was his aim; but thrown from that pretence,

51 The wretch turned loyal in his own defence,

52 And malice reconciled him to his prince.

53 Him, in the anguish of his soul, he served;

54 Rewarded faster still than he deserved.

55 Behold him now exalted into trust;

56 His counsel's oft convenient, seldom just;

57 Even in the most sincere advice he gave,

58 He had a grudging still to be a knave.

59 The frauds, he learned in his fanatic years,

60 Made him uneasy in his lawful gears;

61 At best, as little honest as he could,

62 And, like white witches, mischievously good;

63 To his first bias longingly he leans,

64 And rather would be great by wicked means.

65 Thus framed for ill, he loosed our triple hold;

66 Advice unsafe, precipitous, and bold.

67 From hence those tears, that llium of our woe!

68 Who helps a powerful friend, forearms a foe.

69 What wonder if the waves prevail so far,

70 When he cut down the banks that made the bar?

71 Seas follow but their nature to invade;

72 But he, by art, our native strength betrayed:

73 So Samson to his foe his force confest,

74 And, to be shorn, lay slumbering on her breast.

75 But when this fatal counsel, found too late,

76 Exposed its author to the public hate;

77 When his just sovereign by no impious way

78 Could be seduced to arbitrary sway;

79 Forsaken of that hope, he shifts his sail,

80 Drives down the current with a popular gale,

81 And shows the fiend confessed without a veil.

82 He preaches to the crowd, that power is lent,

83 But not conveyed, to kingly government;

84 That claims successive bear no binding force;

85 That coronation oaths are things of course;

86 Maintains the multitude can never err; 
prostituirse al escándalo da una gran libertad; los santos no comercian, mas pueden traficar: se dio, a pesar de todo, el impío principio, pero un gran timo muestra el juego de su socio. Además, fue su ritmo formal, serio y tranquilo, sobrepasó su ágil genio al pesado fardo mas halló su fortuna en una permanencia, manadas de zoquetes tomando su camino, seguian su consejo, sin darle recompensa; villania e ingenio exigen doble precio.

Su anhelo era el poder, mas perdido este sueño, volvióse leal el misero en su propia defensa, y la propia maldad lo hermanó con su príncipe.

Fue a él a quien sirvió, en la aflicción de su alma, más rápido premiado de lo que merecía. Miradlo bien ahora, digno ya de confianza, útiles sus consejos aunque rara vez justos, aun en el más sincero de los consejos dados, mantenia el rencor de sentirse un villano. Los fraudes, aprendidos en sus años fanáticos, le hicieron preocuparse por su legal entorno; como mucho él era mínimamente honesto y como brujas blancas, nocivamente bueno, con ansía se inclina a su antigua tendencia, prefiriendo ser grande, aún con malvados medios. Tachado asi de malo, perdió el triple asidero, consejo no seguro, rápido y osado.

¡De ahi esas lágrimas, llio de nuestras penas! Quien ayuda a un amigo, a un enemigo evita. ¡Que bueno si las olas se quedaran ahí, al reducir los bancos que forman la barrera!, los mares sólo siguen su tendencia a invadir, mas, con arte, falseó nuestra fuerza materna: confesó asi Sansón su fuerza a su enemigo, $y$, para ser rapado, yace sobre su pecho.

Mas cuando el mal consejo, muy tarde descubierto, a su autor expone al odio de la gente, cuando a su soberano no puede apartarlo, por ningún impio medio, de su arbitrario reino, dejada esa esperanza, iza todas sus velas, y va corriente abajo con la amada galerna y descubre al malvado, declarado, sin velo. Sermonea a las masas que el poder se ha prestado, mas no se ha transferido a ese real gobierno, que la sucesión clama como algo no obligado que las coronaciones son cuestiones de rumbo; mantiene que el gentio jamás se equivoca 
87 And sets the people in the papal chair.

88 The reason's obvious, interest never lies;

89 The most have still their interest in their eyes;

90 The power is always theirs, and power is ever wise.

91 Almighty crowd! thou shortenest all dispute;

92 Power is thy essence, with thy attribute!

93 Nor faith nor reason make thee at a stay;

94 Thou leap'st o'er all eternal truths in thy pindaric way!

95 Athens, no doubt, did righteously decide,

96 When Phocion and when Socrates were tried;

97 As righteously they did those dooms repent;

98 Still they were wise, whatever way they went:

99 Crowds err not, though to both extremes they run;

100 To kill the father, and recall the son.

101 Some think the fools were most as times went then,

102 But now the world's o'erstocked with prudent men.

103 The common cry is even religion's test,

104 The Turk's is at Constantinople best,

105 Idols in India, Popery at Rome,

106 And our own worship only true at home;

107 And true but for the time, 'tis hard to know

108 How long we please it shall continue so;

109 This side to-day, and that to-morrow burns;

110 So all are God-almighties in their turns.

111 A tempting doctrine, plausible and new;

112 What fools our fathers were, if this be true!

113 Who, to destroy the seeds of civil war,

114 Inherent right in monarchs did declare;

115 And, that a lawful power might never cease,

116 Secured succession to secure our peace.

117 Thus property and sovereign sway at last

118 in equal balances were justly cast;

119 But this new Jehu spurs the hot-mouthed horse,

120 Instructs the beast to know his native force,

121 To take the bit between his teeth, and fly

122 To the next headlong steep of anarchy.

123 Too happy England, if our good we knew,

124 Would we possess the freedom we pursue!

125 The lavish government can give no more;

126 Yet we repine, and plenty makes us poor.

127 God tried us once; our rebel fathers fought;

128 He glutted them with all the power they sought,

129 Till, mastered by their own usurping brave,

130 The free-born subject sunk into a slave.

Hikma (2005), 59-81 
y coloca al pueblo en el sillón papal.

Las razones son obvias, el interés no miente, la mayoría aún muestra interés en sus ojos, el poder siempre es suyo, y el poder siempre es sabio. ¡Multitud poderosa! Tu acortas cualquier riña, el poder es tu esencia, y también tu atributo ni razón ni la fe te hacen que permanezcas, credos eternos obvias de manera pindárica! Atenas justamente, sin duda, decidió, cuando Focio y Sócrates fueron puestos a prueba; se arrepintió el destino igual de justamente, mas fueron siempre sabios por doquiera que fueran: la multitud no yerra, aun en lados opuestos, como matar al padre y hacer volver al hijo. Algunos creen que antaño abundaban los tontos, pero en el mundo ahora, abundan los prudentes. Incluso el pregón público de religión es prueba, musulmán es mejor allá en Constantinopla, ídolos en la India, el papado en Roma, y nuestro propio culto sólo sirve ya en casa; y valioso hasta ahora, dificil es saber hasta cuándo querremos que permanezca así; este lado para hoy y aquel para mañana; todos son a su vez Dios-todopoderoso. Tentadora doctrina, plausible y tan nueva, iqué tontos nuestros padres si esto fuera verdad! los que para destruir el germen de la guerra, dieron derecho intrínseco a todos los monarcas, y un poder legal que no cesaria nunca, por conseguir la paz, la sucesión lograron. Por fin, la propiedad y la soberanía fueron depositadas en balanzas iguales; pero este nuevo Jehu ${ }^{5}$ espolea al caballo enseña a la bestia a descubrir su fuerza, a morder el bocado y volar hasta el próximo y escarpado desvío de pura anarquía. ¡Muy contenta Inglaterra, si su bien conociera, entonces poseeria la libertad deseada!

El lujoso gobierno ya no puede dar más, nosotros nos quejamos, todo nos sabe a poco. Dios nos probó antaño; nuestros padres pelearon, les concedió en exceso el poder que pidieron, hasta que conducidos por su usurpador a un ser libre trataron como a un simple esclavo.

${ }^{5}$ Jehu, hijo Jehoshaphat, asesinó al rey de Israel y se proclamó décimo rey de la parte norte de Israel. 
131 We loathe our manna, and we long for quails; $132 \mathrm{Ah}$, what is man, when his own wish prevails! 133 How rash, how swift to plunge himself in ill, 134 Proud of his power, and boundless in his will! 135 That kings can do no wrong, we must believe; 136 None can they do, and must they all receive? 137. Help, heaven! or sadly we shall see an hour, 138 When neither wrong nor right are in their power! 139 Already they have lost their best defence, 140 The benefit of laws, which they dispense; 141 No justice to their righteous cause allowed, 142 But baffled by an arbitrary crowd;

143 And medals graved their conquest to record, 144 The stamp and coin of their adopted lord.

145 The man, who laughed but once to see an ass

146 Mumbling to make the cross-grained thistles pass;

147 Might laugh again to see a jury chaw

148 The prickles of unpalatable law.

149 The witnesses, that leech-like lived on blood, 150 Sucking for them were med'cinally good;

151 But when they fastened on their festered sore, 152 Then justice and religion they forswore;

153 Their maiden oaths debauched into a whore.

154 Thus men are raised by factions, and decried, 155 And rogue and saint distinguished by their side; 156 They rack even Scripture to confess their cause, 157 And plead a call to preach in spite of laws.

158 But that's no news to the poor injured page, 159 It has been used as ill in every age;

160 And is constrained with patience all to take, 161 For what defence can Greek and Hebrew make? 162 Happy, who can this talking trumpet seize; 163 They make it speak whatever sense they please! 164 'Twas framed at first our oracle, to enquire; 165 But since our sects in prophecy grow higher, 166 The text inspires not them, but they the text inspire. 167 London, thou great emporium of our isle, 168 O thou'too bounteous, thou too fruitful Nile! 169 How shall I praise or curse to thy desert? 170 Or separate thy sound from thy corrupted part? 171 I called thee Nile; the parallel will stand; 172 Thy tides of wealth o'erflow the fattened land; 173 Yet monsters from thy large increase we find, 174 Engendered on the slime thou leav'st behind. 175 Sedition has not wholly seized on thee, 176 Thy nobler parts are from infection free. 177 Of Israel's tribes thou hast a numerous band, 
No queremos maná, y codorniz deseamos;

Ah, ¿en qué queda el hombre, al conseguir su antojo?

¡Que impetuoso y rápido, hundirse en la maldad, ufano de su fuerza y con vasto deseo!

Que los reyes no yerran es lo que hay que pensar nunca hacen el mal y ¿han de recibirlo?

¡Ayúdanos, Dios mío! o llegará la hora en que ni el bien ni el mal estarán en sus manos.

Ya han logrado perder su máxima defensa, la bondad de las leyes que ellos mismos dispensan; no sirve la justicia para su justa causa, está desconcertada por la arbitrariedad; y medallas grabadas recuerdan su conquista, el sello y la moneda del señor adoptivo.

El hombre que una vez rió al ver a un asno intentando tragar cardos atravesados podria reírse de nuevo viendo al jurado tragar espinas de una ley totalmente indigesta.

Testigos, cual parásitos que succionan la sangre, absorbian para ellos, cuando era terapéutico; más cuando se agarraron a su podrida llaga, renunciaron a toda religión y justicia, sus promesas de virgen degenerada en furcia. El hombre, por facciones alzado y censurado, y el granuja y el santo distinguidos de lado, maneja hasta la Biblia al defender su causa y en lugar de las leyes suplica un sermón. Pero esto no es nuevo para la herida página, ha sido mal usada como en otras épocas y se siente obligada a aceptar con paciencia, pues ¿qué defensa tienen los hebreos y los griegos? Contentos, quienes pueden asir esta trompeta, le hacen decir aquello que a ellos más les conviene. Para informar fue escrito en principio el oráculo más cuando nuestra secta aumenta en profecias, no les inspira el texto: ellos al texto inspiran.

Tu eres el gran imperio de nuestra isla, Londres, demasiado abundante, tan fértil río Nilo ¿Cómo maldecir puedo o alabar tu desierto? ¿O separar tu parte buena de la corrupta? Te llamo río Nilo, el símil bastará; tus fértiles corrientes riegan tierra abonada, pero encontramos monstruos, tras tus grandes crecidas, engendrados por lodo que tú dejaste atrás.

La sedición no pudo atraparte del todo tu parte más ilustre no ha sido infectada. Las tribus de Israel, muchas son de tu bando, 
178 But still the Canaanite is in the land; 179 Thy military chiefs are brave and true, 180 Nor are thy disenchanted burghers few;

181 The head is loyal which thy heart commands,

182 But what's a head with two such gouty hands?

183 The wise and wealthy love the surest way,

184 And are content to thrive and to obey.

185 But wisdom is to sloth too great a slave;

186 None are so busy as the fool and knave.

187 Those let me curse; what vengeance will they urge,

188 Whose ordures neither plague nor fire can purge;

189 Nor sharp experience can to duty bring,

190 Nor angry heaven, nor a forgiving king!

191 In gospel-phrase their chapmen they betray;

192 Their shops are dens, the buyer is their prey:

193 The knack of trades is living on the spoil;

194 They boast even when each other they beguile.

195 Customs to steal is such a trivial thing,

196 That 'tis their charter to defraud their king.

197 All hands unite of every jarring sect;

198 They cheat the country first, and then infect.

199 They for God's cause their monarchs dare dethrone, 200 And they'll be sure to make his cause their own.

201 Whether the plotting Jesuit laid the plan

202 Of murdering kings, or the French Puritan,

203 Our sacrilegious sects their guides outgo,

204 And kings and kingly power would murder too.

205 What means their traitorous combination less,

206 Too plain to evade, too shameful to confess!

207 But treason is not owned when 'tis descried;

208 Successful crimes alone are justified.

209 The men, who no conspiracy would find,

210 Who doubts, but, had it taken, they had joined,---

211 Joined in a mutual covenant of defence,

212 At first without, at last against, their prince?

213 If sovereign right by sovereign power they scan,

214 The same bold maxim holds in God and man:

215 God were not safe, his thunder could they shun, $216 \mathrm{He}$ should be forced to crown another son.

217 Thus, when the heir was from the vineyard thrown,

218 The rich possession was the murderers' own.

219 In vain to sophistry they have recourse; 
pero la Cananita ${ }^{6}$ aún está en esta tierra, tus jefes militares son valientes y fieles, mas tampoco es pequeño el burgués desencanto; la cabeza que rige sus almas te es fiel, pero ¿de qué te sirve con gota en ambas manos? Los sabios y los ricos quieren ir bien seguros, y se sienten contentos de servir y crecer, mas la sabiduría es de la apatia sierva, nadie hay tan ocupado como el bribón y el tonto. ¿Qué venganza querrán? Maldigo yo a aquellos cuyas ordes no arreglan ni una plaga ni un fuego; ¡una gran experiencia no conduce al deber, ni el cielo enfadado, ni un rey indulgente! Usando el Evangelio venden a sus tratantes, sus tiendas son guaridas, el comprador su presa: la habilidad en el trato reside en el botín; jactándose incluso de engañarse uno al otro. El robar como hábito es cosa tan trivial, que está en sus estatutos defraudar a su rey. Unidas por las manos, esas sectas opuestas al país primero engañan y luego lo infectan. En nombre de Dios osan destronar al monarca, sin dejar de olvidar hacerse con su causa.

Si fue el Jesuita o el francés puritano quien este plan urdió de asesinar a reyes, nuestras sectas sacrílegas su plan han superado, acabando con reyes y con el poder real.

Esto, valor le resta a toda su traición, simple de evitar y ruin de confesar, más la traición no sirve cuando es descubierta, sólo al crimen impune se le da la razón.

Los hombres que no encuentran conspiración alguna, ¿quién duda, una vez hecha, que se han unido a ella, unidos en un mutuo provecho de defensa, primero sin su príncipe, por último contra él? Si el poder del rey miden, mediante sus derechos, la misma y clara máxima se da entre el hombre y Dios si Dios no está seguro, podrian rehuir sus truenos, se vería obligado a coronar otro hijo. Cuando al heredero se le echa del viñedo, las ricas posesiones son para el asesino. En vano han recurrido a la sofisteria;

\footnotetext{
${ }^{6}$ Acab, uno de los reyes de Israel, había sido persuadido por Jezabel, una mujer cananita, de rechazar a Dios e idolatrar a Baal, un dios cananita. Como Acab no se arrepintió y siguió sin reconocer a Dios, Israel fue castigado con años de sequia y hambre, lo que demostraba el poder de Dios y la impotencia de Baal.
} 
220 By proving theirs no plot, they prove 'tis worse, 221 Unmasked rebellion, and audacious force;

222 Which, though not actual, yet all eyes may see,

223 'Tis working in the immediate power to be;

224 For from pretended grievances they rise,

225 First to dislike, and after to despise;

226 Then, cyclop-like, in human flesh to deal,

227 Chop up a minister at every meal;

228 Perhaps not wholly to melt down the king,

229 But clip his regal rights within the ring.

230 From thence to assume the power of peace and war,

231 And ease him, by degrees, of public care:

232 Yet, to consult his dignity and fame,

$233 \mathrm{He}$ should have leave to exercise the name,

234 And hold the cards while commons played the game.

235 For what can power give more than food and drink,

236 To live at ease, and not be bound to think?

237 These are the cooler methods of their crime,

238 But their hot zealots think 'tis loss of time;

239 On utmost bounds of loyalty they stand,

240 And grin and whet like a Croatian band,

241 That waits impatient for the last command.

242 Thus outlaws open villainy maintain;

243 They steal not, but in squadrons scour the plain;

244 And if their power the passengers subdue,

245 The most have right, the wrong is in the few.

246 Such impious axioms foolishly they show,

247 For in some soils republics will not grow:

248 Our temperate isle will no extremes sustain

249 Of popular sway, or arbitrary reign;

250 But slides between them both into the best,

251 Secure in freedom, in a monarch blest;

252 And though the climate, vexed with various winds,

253 Works through our yielding bodies on our minds,

254 The wholesome tempest purges what it breeds,

255 To recommend the calmness that succeeds.

256 But thou, the pander of the people's hearts,

2570 crooked soul, and serpentine in arts,

258 Whose blandishments a loyal land have whored,

259 And broke the bonds she plighted to her lord;

260 What curses on thy blasted name will fall,

261 Which age to age their legacy shall call!

262 For all must curse the woes that must descend on all.

263 Religion thou hast none: thy mercury

264 Has passed through every sect, or theirs through thee.

265 But what thou givest, that venom still remains,

266 And the poxed nation feels thee in their brains.

Hikma (2005), 59-81 
viendo que no hay complot, muestran que es aún peor, rebelión al desnudo y fuerza descarada, que, aunque no es real, todos la pueden ver, trabaja para estar urgente en el poder, pues sabe que se basa en falsos agravantes, primero a molestar, luego a despreciar;

Entonces, como cíclopes ante la carne humana Se comen a un ministro en todas las comidas; quizá por no fundir completamente al rey, mas si por reducir sus derechos reales.

$Y$ entonces asumir la guerra o paz, librarle gradualmente de los problemas públicos: aunque se le consulte, por su dignidad y fama deberia de dejar de ejercer el nombre, y sujetar las cartas del juego a los comunes. ¿Qué propicia el poder, mas comida y bebida çpara vivir mejor, sin tener que pensar?

Estos son los fríos métodos de todos estos crímenes, pero los más fanáticos, creen que es perder el tiempo, y está en la frontera del concepto de lealtad, sonriendo se estimulan, igual que el bando croata, que impaciente aguarda la última de las órdenes. Los bandidos mantienen la abierta villania, no roban, mas en grupos, registran la llanura; y si ante su poder claudica el pasajero, la mayoría manda, los menos se equivocan. Tan impio axioma muestran de forma insulsa pues en algunos campos no crece la república: nuestra moderada isla no mantendrá extremos de popular dominio ni de arbitrario reino; sino aspectos entre ambos, que parecen mejores, en libertad seguros, bajo un monarca beato; y aunque el clima, vejado por vientos muy diversos, trabaja en nuestras mentes, atravesando el cuerpo, la sana tempestad hace purga en su cría, recomendar la calma, que es aquello que triunfa. Mas tú, el alcahuete del corazón humano, oh alma tortuosa, de artes viperinas, tus loas han prostituido a una tierra leal, que ha roto con los lazos que juró a su señor; ¡qué blasfemias caerán en tu maldito nombre, que época tras época pedirá su herencia! Maldigamos las penas que caerán sobre todos. Tú, religión no tienes, tu azogue ha pasado por todas las creencias, o las suyas por ti. Pero lo que tú diste, ese veneno, queda y la nación maldita te siente en sus venas. 
267 What else inspires the tongues, and swells the breasts, 268 of all thy bellowing renegado priests, 269 That preach up thee for God, dispense thy laws, 270 And with thy stum ferment their fainting cause;

271 Fresh fumes of madness raise, and toil and sweat, 272 To make the formidable cripple great? 273 Yet should thy crimes succeed, should lawless power 274 Compass those ends thy greedy hopes devour, 275 Thy canting friends thy mortal foes would be, 276 Thy God and theirs will never long agree;

277 For thine, if thou hast any, must be one,

278 That lets the world and humankind alone;

279 A jolly god, that passes hours too well, 280 To promise heaven, or threaten us with hell; 281 That unconcerned can at rebellion sit, 282 And wink at crimes he did himself commit. 283 A tyrant theirs; the heaven their priesthood paints 284 A conventicle of gloomy, sullen saints;

285 A heaven, like Bedlam, slovenly and sad, 286 Fore-doomed for souls with false religion mad. 287 Without a vision, poets can foreshow 288 What all but fools, by common sense, may know: 289 If true succession from our isle should fail, 290 And crowds profane, with impious arms, prevail, 291 Not thou, nor those thy factious arts engage, 292 Shall reap that harvest of rebellious rage, 293 With which thou flatterest thy decrepit age. 294 The swelling poison of the several sects, 295 Which, wanting vent, the nation's health infects, 296 Shall burst its bag, and, fighting out their way, 297 The various venoms on each other prey. 298 The presbyter, puffed up with spiritual pride, 299 Shall on the necks of the lewd nobles ride; 300 His brethren damn, the civil power defy, 301 And parcel out republic prelacy.

302 But short shall be his reign; his rigid yoke, 
¿Qué otra cosa inspira y llena el corazón de todos tus queridos y renegados párrocos, que te piden por Dios dispensa de tus leyes, y usando tu mosto fermentan su cosecha; humo de locura izan, de sudor y trabajo para engrandecer al terrible lisiado? Si triunfaran sus crimenes, si el poder ilicito consiguiera esos fines, devorar tus anhelos, tus sesgados amigos serian rivales máximos, tu Dios y el de ellos nunca estarian de acuerdo; pues el tuyo ha de ser, si es que tienes uno, el que deja al mundo y al hombre a su suerte; un buen Dios que disfruta con el paso del tiempo, prometiendo el cielo o llevándonos al orco, que ante la rebelión se queda indiferente y hace un guiño ante crímenes que cometió el mismo. Es suyo el tirano, pinta su clero el cielo, una reunión ${ }^{7}$ de oscuros y resentidos santos; un cielo, como Bedlam ${ }^{8}$, triste y descuidado, predestinado a almas, locas por falso credo. Sin visión, los poetas pueden ya presagiar lo que todos conocen, excepto los más tontos, si el legal relevo de esta isla fracasara, y la masa profana triunfa con impias armas ni tú ni ellos precisáis de tus facciosas artes, cosechareis el fruto de la furia rebelde, con la que halagar vuestra era decrépita. El hinchado veneno de las diversas sectas, que buscando aire infectan la salud del país, explotará su bolsa y al luchar por salir, los variados venenos salpicarán a todos. Hinchado el presbítero de orgullo espiritual cabalgará a lomos de los lascivos nobles, maldecirá a su orden, desafiará al poder y se repartirá la mitra del estado.

Mas, breve será el reino, su riguroso yugo y el tirano poder provocarán sectillas;

\footnotetext{
${ }^{7}$ El significado de 'conventicle', tal y como lo recoge The American Heritage Dictionary of the English Language hace referencia a una reunión religiosa, especialmente una reunión secreta o ilegal, como las mantenidas por los disidentes en Inglaterra y Escocia durante los siglos XVI y XVII.

${ }^{8}$ 'Bedlam' es la abreviatura inglesa para 'Bethlehem', nombre de un hospital londinense, originalmente para pobres que sufrieran cualquier tipo de enfermedad y para aquellos que no tuvieran otro lugar donde vivir, de ahi su nombre Bethiehem, que en hebreo significa la casa del pan'; posteriormente, durante el siglo XIV, se comenzó a utilizar parcialmente como asilo para enfermos mentales y con el tiempo, el término 'Bedlam' se incorporó al lenguaje popular con el significado popular de 'casa de confusión'.
} 
303 And frogs and toads, and all the tadpole train,

304 Will croak to heaven for help from this devouring crane.

305 The cut-throat sword and clamorous gown shall jar,

306 In sharing their ill-gotten spoils of war;

307 Chiefs shall be grudged the part which they pretend;

308 Lords envy lords, and friends with every friend

309 About their impious merit shall contend.

310 The surly commons shall respect deny,

311 And jostle peerage out with property.

312. Their general either shall his trust betray,

313 And force the crowd to arbitrary sway;

314 Or they, suspecting his ambitious aim,

315 In hate of kings shall cast anew the frame,

316 And thrust out Collatine, that bore their name.

317 Thus, inborn broils the factions would engage,

318 Or wars of exiled heirs, or foreign rage,

319 Till halting vengeance overtook our age;

320 And our wild labours, wearied into rest,

321 Reclined us on a rightful monarch's breast.

1. ---- Pudet hæc opprobria, vobis

2. Et dici potuisse, et non potuisse refelli. 
y las ranas y sapos, la corte de batracios croarán cobijo, al cielo, de esta grulla glotona.

La atroz daga y el traje ruidoso chocarán al compartir ilícitos botines de la guerra; habrá que dar a jefes las partes que pretenden; los lores a los lores envidian y entre amigos su mérito impio tendrán que disputarse. Los zafios comunes no les tendrán respeto y equipararán propiedad con nobleza.

Venderá el general la confianza de estos y forzará a la masa a arbitrario dominio, y ésta, sospechosa de su ávido propósito, se volcará de nuevo en el odio a los reyes, sacará a Colatino ${ }^{9}$, que horadará su nombre. Asi, peleas innatas librarian las facciones o guerras de herederos, o de afán extranjero hasta que la venganza alcance nuestra época y nuestros laboristas, cansados en descanso, nos dejen sobre el pecho del monarca legitimo.

1. -...- Pudet hæc opprobria, vobis

2. Et dici potuisse, et non potuisse refelli.

\footnotetext{
${ }^{9}$ Colatino era esposo de Lucrecia, una noble romana de la que se prendó el hijo del rey Tarquino; ante el rechazo de la joven a las solicitudes amorosas, el hijo del rey violó a Lucrecia. La patricia reunió a su padre, Lucrecio, a su esposo y a sus familiares para contarles lo que habia ocurrido, acabando inmediatamente con su vida para lavar la afrenta. Bruto, presente en el suicidio, arrancó el puñal que Lucrecia había clavado en su corazón y juró venganza, en lo que sería el fin de la monarquía en Roma y la proclamación de la república en el año 510 a, C. Este hecho precipitó la ruina de la monarquía, supuso la expulsión de los reyes, el nombramiento de los cónsules y el inicio de la época republicana.
} 
Prueba fehaciente de la eficacia y repercusión de The medal es el número de contestaciones que suscitó entre los simpatizantes liberales; de entre estas son especialmente destacables la obra de Samuel Pordage, The medal reversed, a satyr against Persecution (1682) y The medal of John Bayes, a satyr against folly and knavery (1682), de Thomas Shadwell. Esta última fue contestada por Dryden con el poema Mac Flecknoe, or a satyr on the True Blue Protestant poet (octubre, 1682), obra en la que ridiculiza sin piedad a Shadwell.

A modo de conclusión diremos que Dryden consigue con sus poemas satíricos elevar al máximo el pensamiento horaciano nil admirari. Dryden consigue desarrollar un ideal cultural basado en el juicio poético y en la evaluación de méritos; un ideal cultural, que dejará de regirse por el concepto de superioridad en edad, solvencia y poder. Criticando el abuso de poder político y social, Dryden consigue en definitiva, dotar a la sátira de una cierta autoridad, basada en la libertad de pensamiento.

BIBLIOGRAFIA

BLOOM, E. y BLOOM L.: "The Satiric Mode of Feeling.", en Criticism 11 (1969), págs. 115-137.

BLoOM, E. y BLOOM L.: Satire's Persuasive Art, Ithaca, Cornell Univ. Press, 1979.

BrowNING, J. D. (ed.): Satire in the Eighteenth Century, Nueva York, Garland Publishing, 1983.

CARRETTA, V.: The Snarling Muse: verbal and visual political satire from Pope to Churchill, Philadelphia, University of Pennsylvania Press, 1983.

CLARK, J. R.: "Formal Straining: Recent Criticism of Satire.", en College English 32, enero, 1971, págs. 498-505.

JENSEN, J. (ed.): The Satirist's Art, Londres, Indiana University Press, 1972.

KINSLEY, W.: "'The Malicious World' and the Meaning of Satire.", en Genre 3 (Junio, 1970), págs. 137-155.

NOKES, D.: Raillery and Rage: A Study of Eighteenth Century Satire, Nueva York, St. Martin's Press, 1987.

PAGLIARO, H. E. (ed.): Major English Writers of the Eighteenth Century, Nueva York, Free Press, 1969.

Previte-Orton, C. W.: Political Satire in English Poetry, Nueva York, Cambridge University Press, 1968.

Rawson, C.: Satire and Sentiment 1660-1830, Cambridge, Cambridge Univ. Press, 1994.

THORPE, P.: "Free Will, Necessity, and Satire.", en Satire Newsletter 8 (Primavera, 1971), pág. 87. 
THRALL, W. et alii (eds.): A Handbook to Literature, Nueva York, Odyssey Press, 1960.

WALKER, H.: English Satire and Satirists, Nueva York, Octagon Books, 1965.

WEINBROT, Howard D.: Eighteenth-Century Satire: Essays on Text and Context from Dryden to Peter Pindar., Cambridge, Cambridge Univ. Press, 1988.

: "The Pattern of Formal Verse Satire in the Restoration and the Eighteenth Century." PMLA, 80 (1965), 394-401.

WOOD, A. G.: Literary Satire and Theory: a study of Horace, Boileau, and Pope, Nueva York, Garland Publishing, 1985.

YU, C.: Nothing to Admire. The politics of poetic satire from Dryden to Merrill, 2003 